\title{
Evidence for Absorption of Kelp Detritus by the Ribbed Mussel Aulacomya ater Using a New ${ }^{51}$ Cr-Labelled Microsphere Technique
}

\author{
V. Stuart ${ }^{1}$, J. G. Field ${ }^{1}$ and R. C. Newell ${ }^{2}$ \\ ${ }^{1}$ Department of Zoology, University of Cape Town, Rondebosch 7700, South Africa \\ ${ }^{2}$ Institute for Marine Environmental Research, Prospect Place, PIymouth PLI 3DH, United Kingdom
}

\begin{abstract}
A modification of the ${ }^{51} \mathrm{Cr}:{ }^{14} \mathrm{C}$ twin-labelling technique is described in which the food source is labelled with ${ }^{14} \mathrm{C}$ but the ${ }^{51} \mathrm{Cr}$ is enclosed in a polymeric resin membrane and presented as microspheres of a similar diameter to the food particles. This eliminates the major uptake of ${ }^{51} \mathrm{Cr}$ which is transferred to the ctenidia and palps of the suspension-feeding mussel Aulacomya ater (Molina) from detritus labelled with ${ }^{51} \mathrm{Cr}$. The results suggest that although bacterial cultures based on isolates of kelp bacteria can be absorbed with an efficiency of 67 to $70 \%$, the debris itself is also absorbed with an efficiency of approximately $50 \%$. The kelp debris, which forms an important component of the particulate matter potentially available for consumers, may thus represent an important source of carbon for the filter feeding community adjacent to kelp beds. In contrast to the results obtained in other studies with artificial food sources, the data for kelp debris suggest that $A$. ater is able to maintain a positive scope for growth at the concentrations of suspended organic matter which occur under natural conditions in the kelp bed environment.
\end{abstract}

\section{INTROCUCTION}

The decomposition of detrital material and its subsequent utilisation by consumer organisms has been widely studied in marine and freshwater habitats. Since many invertebrates apparently show only a weak ability to digest cellulose, xylan, alginic acid or other structural carbohydrates which make up the bulk of detrital material (Kristensen, 1972) it has been generally supposed that the carbon and, above all, the protein requirements of consumer organisms may be met by absorption of the microbial component of the ingested plant detritus (Newell, 1965, 1979; Darnell, 1967a, b; Odum and De la 'Cruz, 1967; Hargrave, 1970a, b, 1971. Fenchel, 1972; De la Cruz and Poe, 1975; Kofoed, 1975; Tenore, 1975; Moriarty, 1977)

One of the difficulties in interpreting the significance of the microbiota in meeting the nutritional requirements of consumer organisms is that the biomass of bacteria in the sediments may be too low to meet the estimated carbon or nitrogen requirements of the consumer organisms (Baker and Bradnam, 1976;
Wetzel, 1977; Jensen and Siegismund, 1980). Tunnicliffe and Risk (1977), for example, calculated that the bivalve Macoma balthica could meet only $0.2 \%$ of its nitrogen requirements from the microbial biomass in the sediments. Again, Cammen et al. (1978) and Cammen $(1980 \mathrm{a}, \mathrm{b})$ have estimated that only 25 to $45 \%$ of the carbon requirements of the deposit feeding polychaete Nereis succinea could be met by utilisation of microbial carbon.

These results suggest that some of the carbon necessary to balance the energy budget may be derived by direct utilisation of plant debris itself, a conclusion which is supported by studies on the relation between primary production and consumption requirements in kelp communities (Newell et al., 1982). Other studies, however, suggest that because microbial production is often high relative to the standing stocks in the sediment, the requirements of consumer organisms could be met by utilisation of a relatively small proportion of microbial production. Hargrave (1970a), for example, showed that the absorption efficiency of detritus by the amphiod Hyalella azteca was controlled by the pro- 
portion of living to dead matter in the detritus and that in this species ingestion of less than $19 \%$ of the daily microflora production would be sufficient to meet the energy requirements of the consumer.

An alternative approach to such estimates of microbial bionass relative to carbon requirements is to measure the absorption of detritus and its associated microbial community directly. Simple gravimetric techniques involving quantitative estimation of consumption and faecal output (Phillipson, 1960; Fuji 1962; Lasenby and Langford, 1973) as well as various tracer methods based on the ingestion and egestion of ${ }^{14} \mathrm{C}$ labelled food have been used (Marshall and Orr, 1955; Sorokin and Panov, 1966; Southwood, 1966; Sorokin 1968 ). But in many organisms it is difficult to measure consumption and faecal output quantitatively, especially as some reingestion of fragmented faeces occurs in experimental studies on filter feeders. In these cases it is also possible to measure absorption efficiency by comparison of the organic: inorganic ratio in the food and faeces without quantitative data for consumption and egestion (Conover, 1966). The method requires that no net absorption of inorganic material or secretion of organic matter occurs in the passage through the gut, although - as has been pointed out by Calow and Fletcher (1972) - this requirement may not be met in some deposit feeders. They described an alternative method in which the food is labelled with ${ }^{51} \mathrm{Cr}$ and ${ }^{14} \mathrm{C}$ (see also Wightman, 1975). Since the ${ }^{51} \mathrm{Cr}$ is passed with minimal absorption through the gut and it is not subject to interference by organic secretions from the gut, simultaneous activity of both tracers in the food and faeces can be used to estimate absorption efficiency.

This method has been employed in studies on the absorption efficiency in 2 freshwater gastropods (Calow and Fletcher, 1972), a coleopteran larva (Wightman, 1975), and in the deposit-feeding polychaete Nereis succinia (Cammen et al., 1978). In each case the ${ }^{51} \mathrm{Cr}$ isotope was added in the form of ${ }^{51} \mathrm{Cr} \mathrm{Cl}_{3}$ which satisfactorily labelled the food, although it is not certain whether this was achieved by absorption or passive adsorption (Calow and Fletcher, 1972). The main requirement for successful use of this method is that the ${ }^{51} \mathrm{Cr}$ is not absorbed in significant quantities into the tissues and passes quantitatively to the faeces. Unfortunately, preliminary experiments on the utilisation of ${ }^{51} \mathrm{Cr}$-labelled kelp debris by the filter-feeding ribbed mussel Aulacomya ater showed very variable adsorption values for ${ }^{51} \mathrm{Cr}$ onto the ctenidia, palps and digestive gland ranging from $17 \%$ to $45 \%$ (mean $33.3 \pm$ $11.5 \%$ S.D.), suggesting that the ${ }^{51} \mathrm{Cr}$ may be primarily adsorbed onto the food particles and can be subsequently transferred to epithelia with a large surface area.
Although this problem may be of less importance in deposit feeders or grazing organisms than in filterfeeding organisms where large volumes of water are drawn across the ctenidia, it was necessary to use a modified twin-labelling technique, in which the ${ }^{51} \mathrm{Cr}$ was enclosed in inert microspheres of mean diameter $15.6 \pm 1.2 \mu \mathrm{m}$ to prevent a major adsorption of the marker. This paper presents the results of a series of experiments on the uptake of microbial and detrital material from debris by the ribbed mussel Aulacomya ater using kelp detritus labelled with ${ }^{14} \mathrm{C}$ and ${ }^{51} \mathrm{CI}$ labelled microspheres. This allowed an assessment of the trophic significance of detrital material in the water column for the filter feeding mussels which dominate the consumer community surrounding kelp beds of the Cape Peninsula, South Africa.

\section{MATERIALS AND METHODS}

\section{Labelling Techniques}

A comparison was made between the absorption of phytoplankton cells, such as are commonly used in experimental studies on the energetics of bivalves, detrital material which characterises the water column near to kelp beds, and bacteria. In each case it was necessary to label the food source with ${ }^{14} \mathrm{C}$ and to mix this with ${ }^{51} \mathrm{Cr}$-labelled microspheres of a similar diameter. The microspheres comprising ${ }^{51} \mathrm{Cr}$ enclosed in a polymeric resin membrane (NEN-TRAC microspheres, New-England Nuclear) are identical with those routinely used in blood circulation studies (Bockman and Ferguson, 1978; Hobson et al, 1978) and were of $15.6 \pm 1.2 \mu \mathrm{m}$ diameter chosen to coincide with the mean diameter of particles in the water column near the kelp bed from which the mussels were collected (Field et al., 1980). In practice it was convenient to use approximately $10 \mu \mathrm{Ci}{ }^{51} \mathrm{Cr}(100 \mathrm{ml})^{-1}$ suspended food material since this gave similar counts to the ${ }^{14} \mathrm{C}$ label incorporated into the food.

$$
{ }^{14} \mathrm{C} \text {-Labelling of Phytoplankton }
$$

Labelled phytoplankton cells were prepared by the adition of $10 \mu \mathrm{Ci} \mathrm{NaH}{ }^{14} \mathrm{CO}_{3}(100 \mathrm{ml})^{-1}$ of an actively growing culture of Dunaliella primolecta in Walne's medium and incubation for $6 \mathrm{~d}$ at $12.5^{\circ} \mathrm{C}$ under constant illumination provided by 3 double $20 \mathrm{~W}$ fluorescent lights (Agro-lite) at $10 \mathrm{~cm}$ distance giving a combined intensity of $190 \mu \mathrm{E} \mathrm{m}^{-2} \mathrm{~s}^{-1}$. Excess label was removed by centrifugation at $3000 \mathrm{xg}$ for $15 \mathrm{~min}$ and resuspension of the pellet in $0.45 \mu \mathrm{m}$ filtered seawater. This procedure was repeated 3 times prior to the addition of the ${ }^{51} \mathrm{Cr}$-labelled microspheres. 


\section{${ }^{14} \mathrm{C}$-Labelling of Kelp Material}

Small intact Laminaria pallida, complete with holdfasts, were collected from Oudekraal on the West coast of the Cape Peninsula, South Africa, and were placed individually in a series of cylindrical perspex containers, each filled with $810.45-\mu \mathrm{m}$ filtered seawater which was circulated with small pumps. $300 \mu \mathrm{Ci} \mathrm{Na}$ $\mathrm{H}^{14} \mathrm{CO}_{3}$ was added to each container and the plants incubated at $10^{\circ} \mathrm{C}$ for 2 wk under a constant light source. The water was replaced with freshly filtered ${ }^{14} \mathrm{C}$-labelled seawater each 3 to $4 \mathrm{~d}$ to minimise bacterial growth. After incubation, the plants were rinsed in $10 \% \mathrm{HCl}$ to remove adsorbed ${ }^{14} \mathrm{C}$, freeze-dried, milled and sieved to obtain particles of $<37 \mu \mathrm{m}$ diameter. Weighed quantities were then made up in fresh seawater, and aged for up to $18 \mathrm{~d}$ at $12.5^{\circ}$. Kelp debris incubated in seawater is subject to an initial colonisation by bacteria whose biomass increases over a period of 4 to $6 \mathrm{~d}$ before coming into equilibrium with a mixed population of grazing Protozoa (Linley and Newell, 1981; Linley et al., 1981; Newell and Lucas, 1981). Experiments were therefore carried out on freshly powdered ${ }^{14} \mathrm{C}$-labelled kelp debris and on material which had been colonised by microbes which are known to take up ${ }^{14} \mathrm{C}$-label from algal exudates (Larsson and Hagström, 1979; Schleyer, 1980). This allowed comparison between the absorption of kelp debris itself and that of the microbial: debris complexes which occur in the water column. After ageing, the material was centrifuged and rinsed 3 times before adding ${ }^{51} \mathrm{Cr}$-labelled microspheres to the food source.

\section{${ }^{14} \mathrm{C}$-Labelling of Bacteria}

Thirty-two strains of bacteria isolated from decomposing kelp have been recombined to form a stock culture of kelp-derived bacteria which was stored at $4{ }^{\circ} \mathrm{C}$ (Dr. F. Robb, Dept. of Microbiology, University of Cape Town). A 1-ml inoculum of culture was placed in a medium containing $1 \mathrm{~g}$ casamino acids (DIFCO) and $1 \mathrm{~g} \mathrm{D}$-mannitol in $100 \mathrm{ml}$ filtered seawater and incubated at $30^{\circ} \mathrm{C}$ in darkness overnight on a rotary shaker. The bacteria were then harvested following centrifugation at $15000 \times \mathrm{g}$ for $15 \mathrm{~min}$ and resuspended in a $1 \%$ casamino acid solution to an optical density of 0.2 at $600 \mathrm{~nm}$ using a Bausch and Lomb (Spectronic 600E) spectrophotometer. $40 \mu \mathrm{Ci}{ }^{14} \mathrm{C}$-mannitol were then added per $100 \mathrm{ml}$ culture. After $4 \mathrm{~h}$ incubation at $30^{\circ} \mathrm{C}$ in darkness, excess label was removed by successive centrifugation at $15000 \times \mathrm{g}$ and the bacterial pellet resuspended in $100 \mathrm{ml} 0.2 \mu \mathrm{m}$ filtered autoclaved seawater. Approximately $10 \mu \mathrm{Ci}^{51}$ labelled microspheres were then added per $100 \mathrm{ml}$ bacterial suspension immediately prior to the feeding experiments.

\section{Experimental Procedure}

Aulacomya ater (Molina) were collected at weekly intervals by SCUBA diving from a depth of 10 to $20 \mathrm{~m}$ at Oudekraal on the west coast of the Cape Peninsula, South Africa. Preliminary experiments showed no significant difference in absorption efficiencies between individuals of 25 to $75 \mathrm{~mm}$ length, hence these experiments were conducted on mussels of approximately $50 \mathrm{~mm}$ length $(0.66 \mathrm{~g} \pm 0.17 ; \mathrm{n}=94)$. The shells were cleaned of encrusting organisms, care being taken to retain the byssus attachments of the mussels to a neighbouring shell. The shell substratum to which the mussel was attached was fastened to a grid suspended in a beaker containing $1.510 .45-\mu \mathrm{m}$ filtered seawater circulated with a magnetic stirrer. After approximately $2 \mathrm{~h}$ at $12.5^{\circ} \mathrm{C}$, which is similar to the temperature of the water from which the mussels were collected, a known volume of ${ }^{14} \mathrm{C}:{ }^{51} \mathrm{Cr}$-labelled food was added to the beaker and the concentration kept relatively constant by further addition of an appropriate volume of labelled food at intervals of $30 \mathrm{~min}$. After $4 \mathrm{~h}$ the water was replaced with filtered seawater to which the same concentration of unlabelled food was added. The method is based upon the assumption that there is no discrimination between particles of different types, which is in accordance with most literature on mussels (Foster-Smith, 1975a, b; Winter, 1978). However, recent investigations into the amount of algal material in the pseudofaeces in relation to that in surrounding water have suggested that bivalves do exhibit some degree of particle selection (Kiørboe et al., 1980; Kiørboe and Møhlenberg, 1981). If this is the case absorption results obtained after the production of pseudofaeces must be treated with caution. However, preliminary experiments showed that pseudofaeces were not produced at concentrations $<6 \mathrm{mg} \mathrm{l}^{-1}$ (dry mass), indicating that all the material was ingested at these concentrations.

Since gut passage time is approximately $5 \mathrm{~h}$ (see $\mathrm{p}$. 266), and feeding with labelled food was carried out for $4 \mathrm{~h}$, the passage of labelled material should have been accomplished in approximately $9 \mathrm{~h}$. After this the absorption efficiency could be influenced by the declining residual carbon available in the gut. Faeces were therefore collected each $30 \mathrm{~min}$ for up to $9 \mathrm{~h}$ with a Pasteur pipette and placed in glass scintillation vials for subsequent measurement. 


\section{Preparation and Counting}

Samples of food material on $1 \mu \mathrm{m}$ Nuclepore membranes and faeces were digested with $1 \mathrm{ml}$ Soluene350 tissue solubiliser (Packard) and incubated at $40^{\circ} \mathrm{C}$ for $4 \mathrm{~h}$ or until digestion was complete. However, in order to ensure complete digestion of algal cell walls (Lobban, 1974), $200 \mu \mathrm{I} 60 \%$ perchloric acid was added to all phytoplankton samples. The digested material was subsequently bleached to reduce quenching by the additon of $500 \mu \mathrm{l}$ isopropanol and $200 \mu \mathrm{l}$ $35 \% \mathrm{H}_{2} \mathrm{O}_{2}$, followed by incubation at $40^{\circ} \mathrm{C}$ for a further 2 to $4 \mathrm{~h} .10 \mathrm{ml}$ of Dimilume scintillation cocktail (Packard) was added to each sample and after $6 \mathrm{~h}$ equilibration $B$-emissions were counted for $10 \mathrm{~min}$ on a Packard Tricarb liquid scintillation spectrophotometer (Modell 3385). Counts were made on up to 10 faecal samples per individual, depending on material available, and background counts from 6 vials containing scintillation cocktail only were subtracted from all experimental values.

A method for simultaneous counting of both ${ }^{51} \mathrm{Cr}$ and ${ }^{14} \mathrm{C}$ has been outlined by Sheppard and Marlow (1971) using a narrow band tritium window (Channel A) and a conventional ${ }^{14} \mathrm{C}$ window (Channel B). Quench curves were plotted using ${ }^{14} \mathrm{C}$-hexadecane and ${ }^{51} \mathrm{Cr}$ microspheres quenched with chloroform. Tracer counts in each window, expressed as percent of total counts, were plotted against the external standard ratio (E.S.R.). From this relationship the relative contribution of each isotope to the counts in each window can be read off and used to construct sumultaneous equations which give the counts per minute (CPM) of each isotope (see also Wightman, 1975). These values can also be calculated, rather than read off, and in the case of our data yielded the multiple regression equations shown in Table 1.

Table 1. Multiple regression equations relating relative counting efficiency (\%) to external standard ratio (ESR) in order to calculate the relative proportions of the isotopes in each channel with quenching (Wightman, 1975). The stepwise regression analysis was based on powers of ESR from 1 to 6 , using $P=.05$ for inclusion. Each point was the mean of 6 replicates

\begin{tabular}{|c|c|c|c|c|}
\hline $\begin{array}{c}\text { Chan- } \\
\text { nel }\end{array}$ & $\begin{array}{l}\text { Iso- } \\
\text { tope }\end{array}$ & Equation & $r^{2}$ & $\mathrm{~N}$ \\
\hline A & ${ }^{14} \mathrm{C}$ & $\%=70.88-80.56 \mathrm{ESR}$ & 0.9930 & .10 \\
\hline B & ${ }^{14} \mathrm{C}$ & $\%=69.62+1.271 \mathrm{ESR}^{5}-1654 \mathrm{ESR}^{6}$ & 0.9993 & 10 \\
\hline A & ${ }^{51} \mathrm{Cr}$ & $\%=12.73+341.0 \mathrm{ESR}^{3}$ & 0.9921 & 6 \\
\hline B & ${ }^{51} \mathrm{Cr}$ & $\%=19.15-20.83 \mathrm{ESR}+63.6 \mathrm{ESR}^{3}$ & 0.9994 & 6 \\
\hline
\end{tabular}

As pointed out by Cammen (1977) it is also necessary to know the disintegrations per minute (DPM) of each isotope which can be calculated using the following equation to give the amount of quenching $(\%)$ of each isotope:

$$
\begin{gathered}
\%{ }^{14} \mathrm{C}=87.98+700.7 \mathrm{ESR}^{5}-917.9 \mathrm{ESR}^{6} \\
\left(\mathrm{r}^{2}=0.9970 ; \mathrm{N}=10\right) \\
\%{ }^{51} \mathrm{Cr}=23.57+347.83 \mathrm{ESR}^{3}\left(\mathrm{r}^{2}=0.9959 ; \mathrm{N}=6\right)
\end{gathered}
$$

The output from the scintillation counter recording the ESR, and CPM in channels A and B was fed to a Hewlett Packard 3352 B Laboratory Data System which converted the data to DPM using a program written from the above equations (see also Table 1). The absolute counting efficiency CPM/DPM added of the unquenched samples was $95.04 \%$ for ${ }^{14} \mathrm{C}$ and $16.9 \%$ for ${ }^{51} \mathrm{CrCl}_{3}$.

\section{${ }^{51} \mathrm{Cr}:{ }^{14} \mathrm{C}$ Ratio in Food and Faeces}

The ratio of ${ }^{51} \mathrm{Cr}:{ }^{14} \mathrm{C}$ in the food was determined from 2 sources: that in the concentrated media prior to addition to the experimental vessel, and that in each experimental vessel. No significant difference in the ${ }^{51} \mathrm{Cr}:{ }^{14} \mathrm{C}$ ratio was obtained between concentrated or food samples from the experimental media. Concentration of food by filtration onto a $1-\mu \mathrm{m}$ nuclepore membrane filter also had no significant effect on the ${ }^{51} \mathrm{Cr}$ : ${ }^{14} \mathrm{C}$ ratio. The mean value obtained from a total of 10 or more samples was then used to calculate the ${ }^{51} \mathrm{Cr}:{ }^{14} \mathrm{C}$ ratio of the food sources. The ratio of ${ }^{51} \mathrm{Cr}:{ }^{14} \mathrm{C}$ in the faeces was calculated from the mean of all samples which had counts in excess of 100 CPM over background and in order to avoid corrections for ${ }^{51} \mathrm{Cr}$ decay, food and faecal samples were counted in batches on the same day.

The absorption efficiency was then calculated from the ${ }^{51} \mathrm{Cr}:{ }^{14} \mathrm{C}$ ratio in the food and faeces using the following formula:

Absorption Efficiency: $1-\left[\left({ }^{51} \mathrm{Cr} D P M /{ }^{14} \mathrm{C} D P M\right.\right.$ food $) \div$ $\left({ }^{51} \mathrm{Cr}\right.$ DPM $/{ }^{14} \mathrm{C}$ DPM faeces)] X 100

Settlement of both ${ }^{14} \mathrm{C}$-labelled food particles and ${ }^{51} \mathrm{Cr}$-labelled microspheres over a period of $4 \mathrm{~h}$ showed that the DPM for ${ }^{51} \mathrm{Cr}$ and ${ }^{14} \mathrm{C}$ in the media fell by approximately $13 \%$ in both cases $\left({ }^{51} \mathrm{Cr}\right.$ DPM $=1319.64 \mathrm{e}^{-0.05 t}, \mathrm{r}^{2}=0.33 ;{ }^{14} \mathrm{C}$ DPM $=1133.67 \mathrm{e}^{-0.03 t}$, $\mathrm{r}^{2}=0.37$, where $\mathrm{t}=$ time in hours) resulting in a constant $\mathrm{Cr} / \mathrm{C}$ ratio throughout the experiment. Settlement was thus regarded as negligible in the 30 -min intervals between successive additions of food.

\section{Correction for ${ }^{51} \mathrm{Cr}$ Retention}

Since a requirement of the ${ }^{51} \mathrm{Cr}:{ }^{14} \mathrm{C}$ method is that the retention of ${ }^{51} \mathrm{Cr}$ in the test animal is low, and can be corrected for, it was necessary to determine ${ }^{51} \mathrm{Cr}$ 
retention from the microspheres. Preliminary 4-h feeding experiments using kelp debris dyed with Rose Bengal showed that stained particles first appeared in the faeces 3.5 to $7 \mathrm{~h}$ after feeding, and that dyed particles could be detected in the faeces for up to $24 \mathrm{~h}$. In order to estimate ${ }^{51} \mathrm{Cr}$ retention, 5 mussels of different sizes were fed a ration of $3 \mathrm{mg} \mathrm{l}^{-1}$ dry mass of aged kelp detritus mixed with ${ }^{51} \mathrm{Cr}$-microspheres over a period of $4 \mathrm{~h}$. They were then fed unlabelled food at the same concentration for a further $4 \mathrm{~h}$. All the faeces produced during this period and over the following 16 $\mathrm{h}$ were then collected, digested and the DPM determined. The ${ }^{51} \mathrm{Cr}$ activity in 3 replicate weighed samples of pooled body tissue was also analysed. Absorption of ${ }^{51} \mathrm{Cr}$ was then calculated from the following expression (after Cammen et al., 1978):

${ }^{51} \mathrm{Cr}$ absorption = body burden $(\mathrm{DPM}) /$ faeces + body burden (DPM) It was found that Aulacomya ater retained only $4.5 \%$ ( $\pm 1.22 \%$ S.D.) of the ${ }^{51} \mathrm{Cr}$ microspheres and all faeces counts were corrected accordingly. This value is considerably lower than the values reported by Calow and Fletcher (1972), Wightman (1975) and Cammen et al. (1978), suggesting that the twin-labelling method can be satisfactorily extended to filterfeeding organisms by the use of ${ }^{51} \mathrm{Cr}$-labelled microspheres.

\section{RESULTS AND DISCUSSION}

\section{Absorption of Dunaliella primolecta: Comparison of Conover Ratio and ${ }^{51} \mathrm{Cr}$-Labelled Microsphere Methods}

Consumption and absorption efficiencies of the ribbed mussel Aulacomya ater have been studied in some detail by Griffiths and King (1979). They use a diet of Dunaliella primolecta rather than the particulate debris which occurs in the water column under natural conditions, and calculated the absorption efficiency by the Conover ratio. It is thus of interest to compare the results of the ${ }^{51} \mathrm{Cr}$-microsphere technique with those obtained by Griffiths and King (1979) on D. primolecta before reporting the results for natural kelp debris.

The results are summarised in Table 2. Although the absorption efficiency calculated for concentrations of $10 \times 10^{6}$ cells $1^{-1}$ by the ${ }^{51} \mathrm{Cr}:{ }^{14} \mathrm{C}$ method are higher than those recorded by Griffiths and King (1979), no standard error data are available for their data, and it is not possible to determine whether the results differ significantly from each other. At lower concentrations, however, it is clear that the absorption efficiencies calculated for Dunaliella primolecta by the 2 methods are generally comparable.

Despite the widespread use of laboratory-cultured phytoplankton in studies on the physiological ener-
Table 2. Aulacomya ater. Absorption efficiency of Dunaliella primolecta by individuals held at $12.5^{\circ} \mathrm{C}$, at 2 different ration levels using the twin tracer method, compared with results obtained by Griffiths and King (1979) for similar conditions

\begin{tabular}{|ccccc|}
\hline $\begin{array}{c}\text { Cell con- } \\
\text { centration } \\
\left.\times 10^{6}\right)^{-1}\end{array}$ & $\begin{array}{c}\text { Shell } \\
\text { length } \\
\text { (mm) }\end{array}$ & $\begin{array}{c}\text { Number } \\
\text { of } \\
\text { runs }\end{array}$ & $\begin{array}{c}\text { Mean absorption } \\
\text { efficiency } \\
( \pm \text { S.E.) }\end{array}$ & $\begin{array}{c}\text { AE from } \\
\text { Griffiths } \\
\text { \& King (1979) }\end{array}$ \\
\hline 5 & 50 & 4 & $56.27( \pm 5.51)$ & 61 \\
& 75 & 3 & $58.76( \pm 2.91)$ & 52 \\
10 & 50 & 9 & $42.50( \pm 11.68)$ & 29 \\
& 75 & 5 & $37.71( \pm 6.85)$ & 30 \\
\hline
\end{tabular}

getics of marine molluscs (for reviews see Bayne, 1976; Bayne and Newell, in press), there is now a good deal of information which suggests that the results of such studies can be applied only with difficulty to the absorption of plant debris under natural conditions (Bayne et al., 1979; Widdows et al., 1979; Griffiths, 1980; Vahl, 1980). Year round observations at the collection site revealed that phytoplankton formed an average of only $14 \%$ of the particulate organic matter (V. Stuart, unpubl.). A series of experiments was therefore carried out on the absorption of debris which under natural conditions forms a major component of the particulate material in the water column near kelp beds.

\section{Absorption of the Bacterial Component of Kelp Debris}

As pointed out on p. 263, the utilisation of bacteria by marine deposit feeders has been widely reported in the literature, and early studies on some mussels suggest that they are able to utilise bacteria as a food resource (Bayne, 1976; Newell, 1979). Experiments with ${ }^{51} \mathrm{Cr}$ : ${ }^{14} \mathrm{C}$-labelled mixed populations of cultured kelp bacteria which are slightly larger than natural populations $(1.3 \times 0.4 \mu \mathrm{m}$ compared with $<1 \mu \mathrm{m})$, show that the bactérial component of kelp debris is absorbed with a high efficiency by Aulacomya ater (Table 3)

The activity of ${ }^{14} \mathrm{C}$ label after $24 \mathrm{~h}$ appears principally in the digestive gland, with some activity in the

Table 3. Aulacomya ater. Absorption efficiency ( \pm S. E.) of free ${ }^{14} \mathrm{C}$-labelled bacteria as well as ${ }^{14} \mathrm{C}$-labelled bacteria attached to unlabelled kelp detritus at a concentration of $3 \mathrm{mg} \mathrm{l}^{-1}$ dry mass at $12.5^{\circ} \mathrm{C}$

\begin{tabular}{|lccc|}
\hline $\begin{array}{c}\text { Bacterial } \\
\text { density }\end{array}$ & $\begin{array}{c}\text { Absorption } \\
\text { efficiency }\end{array}$ & $\begin{array}{c}\text { No. of } \\
\text { samples }\end{array}$ & $\begin{array}{c}\text { No. of } \\
\text { runs }\end{array}$ \\
\hline $2 \times 10^{6} \mathrm{ml}^{-1}$ & $\begin{array}{r}\text { ( } \pm \mathrm{S} . \mathrm{E} .) \\
( \pm 1.30)\end{array}$ & 20 & 5 \\
$6 \times 10^{6} \mathrm{ml}^{-1}$ & $70.28( \pm 0.46)$ & 14 & 3 \\
$6 \times 10^{6} \mathrm{ml}^{-1}$ on detritus & $63.08( \pm 3.81)$ & 28 & 5 \\
\hline
\end{tabular}


Table 4. Aulacomya ater. Mean activity of ${ }^{14} \mathrm{C}$ and ${ }^{5 i} \mathrm{Cr}\left(\mathrm{DPM} \mathrm{mg}{ }^{-1} \pm \mathrm{S}\right.$. D.) on at least 2 replicate samples of digestive gland and gill tissue. Test individuals were fed for $4 \mathrm{~h}$ at $12.5^{\circ} \mathrm{C}$ on a diet of ${ }^{14} \mathrm{C}$-labelled bacteria plus ${ }^{51} \mathrm{Cr}$-labelled microspheres, and left for a further $20 \mathrm{~h}$ for gut clearance. Variability between individuals is due to differing feeding activity

\begin{tabular}{|c|c|c|c|c|}
\hline \multirow{2}{*}{$\begin{array}{c}\text { Individual } \\
\text { No. }\end{array}$} & \multicolumn{2}{|c|}{ Digestive gland } & \multicolumn{2}{|c|}{ Gill tissue } \\
\hline & ${ }^{14} \mathrm{C}( \pm \mathrm{S} . \mathrm{D})$. & ${ }^{51} \mathrm{Cr}( \pm \mathrm{S} . \mathrm{D})$. & ${ }^{14} \mathrm{C}( \pm S . D)$. & ${ }^{51} \mathrm{Cr}( \pm$ S. D. $)$ \\
\hline 1 & $11,840.22( \pm$ & $1,045.24( \pm 1,472.23)$ & $1.897 .65( \pm 58.22)$ & $219.71( \pm 65.41)$ \\
\hline 2 & $4,199.83( \pm 1,418.69)$ & $41.34( \pm 58.46)$ & $1,189.70( \pm 109.10)$ & $146.40( \pm 27.06)$ \\
\hline 3 & $307.63( \pm \quad 1.30)$ & $36.631 \pm$ & $49.50( \pm 4.59)$ & $90.55( \pm 5.23)$ \\
\hline 4 & $4,124.91$ & $15.511 \pm$ & $822.21( \pm$ & $90.55( \pm 2.36)$ \\
\hline 5 & $1,033.111 \pm$ & $13.77( \pm$ & - & - \\
\hline 6 & $2,259.11 i \pm$ & $185.98( \pm$ & - & - \\
\hline 7 & $10,325.51 \nmid \pm$ & $121.50( \pm 174.39)$ & - & - \\
\hline
\end{tabular}

gills demonstrating active absorption of bacterial ${ }^{14} \mathrm{C}$ into the digestive gland (Table 4 ). A small proportion of the ${ }^{51} \mathrm{Cr}$ microspheres are retained on the gills and in the digestive gland which we account for in our $4.5 \%$ correction factor (see p. 267).

This high absorption efficiency of bacteria appears to be unaffected by the presence of the particulate debris to which they are attached. When $6 \times 10^{6}$ cells $\mathrm{ml}^{-1}$ labelled kelp bacteria were allowed to colonise 3 $\mathrm{mg} \mathrm{I}^{-1}$ powered kelp debris, they were absorbed with an efficiency of $63 \%$ compared with $70 \%$ for a similar concentration of bacteria alone (Table 3 ). These values are generally similar to those reported by Sorokin (1972) for a variety of marine invertebrates fed on bacterial diets but give no information on the possible utilisation kelp debris itself.

\section{Absorption of Kelp Detritus}

Labelled kelp debris aged for up to $18 \mathrm{~d}$ was fed to mussels over a period of $4 \mathrm{~h}$ at a concentration of $3 \mathrm{mg}$ dry mass $I^{-1}$ which is equivalent to the yearly mear. dry mass of particulate matter occurring at a depth of $20 \mathrm{~m}$ at the collection sites at Oudekraal (Field et al., $1980 ;$ V. Stuart, unpubl.). After a further $4 \mathrm{~h}$ of feeding with a similar concentration of unlabelled debris (see p. 265), the ${ }^{51} \mathrm{Cr}:{ }^{14} \mathrm{C}$ ratios of food and faeces were calculated. The results are summarised in Table 5

Table 5. Aulacomya ater. Absorption efficiency $(\%)$ at $12.5^{\circ} \mathrm{C}$, of kelp detritus aged for up to $18 \mathrm{~d}$, and dry bacterial biomass $\left(\mathrm{mg} \mathrm{l}^{-1}\right)$ of the food ration

\begin{tabular}{|ccccc|}
$\begin{array}{c}\text { Age of } \\
\text { detritus } \\
\text { (d) }\end{array}$ & $\begin{array}{c}\text { Bacterial } \\
\text { biomass } \\
\left(\mathrm{mg} \mathrm{l}^{-1} \mathrm{dry}\right)\end{array}$ & $\begin{array}{c}\text { Mean absorption } \\
\text { efficiency } \% \\
( \pm \text { S.E. })\end{array}$ & $\begin{array}{c}\text { No. of } \\
\text { runs }\end{array}$ & $\begin{array}{c}\text { No. of } \\
\text { samples }\end{array}$ \\
\hline 0 & 0 & $48.24( \pm 4.04)$ & 10 & 20 \\
3 & 0.046 & $50.89( \pm 8.71)$ & 3 & 8 \\
6 & 0.144 & $51.31( \pm 4.78)$ & 5 & 15 \\
12 & 0.076 & $47.28( \pm 5.99)$ & 3 & 15 \\
18 & 0.011 & $47.91( \pm 6.15)$ & 4 & 10 \\
\hline
\end{tabular}

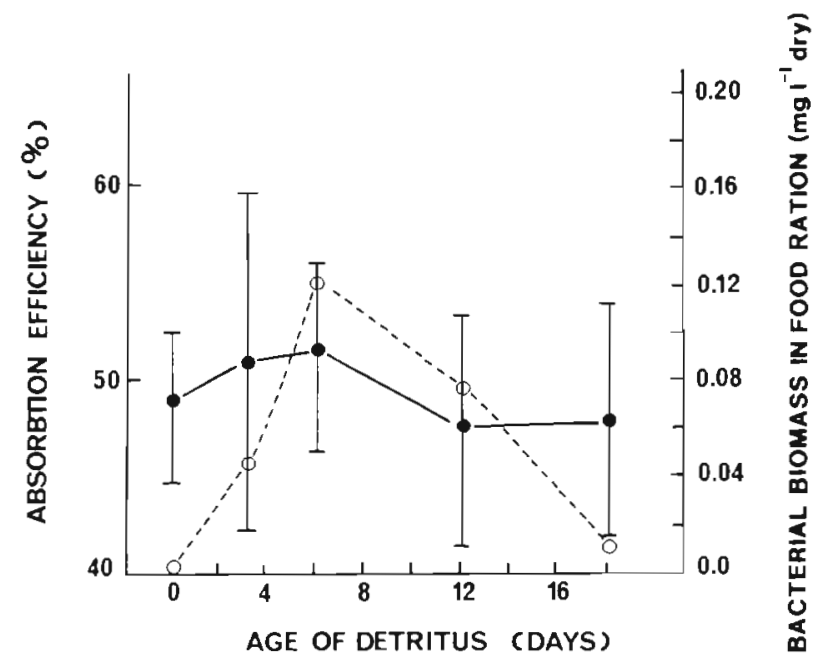

Fig. 1. Aulacomya ater. Absorption efficiency ( \pm 1 S.E.) of individuals fed on $3 \mathrm{mg} 1^{-1}$ (dry mass) of kelp material aged for up to $18 \mathrm{~d}$ (closed circles). Open circles: bacterial biomass of food samples

which also shown the bacterial biomass, calculated following the technique of Linley et al. (1981).

It can be seen that Aulacomya ater is capable of absorbing carbon from fresh kelp detritus with an efficiency of approximately $48 \%$ compared with 67 to $70 \%$ for bacteria alone. With increasing age and bacterial component, there was some increase in absorption efficency to $51.3 \%$ on Day 6 , corresponding with the maximal biomass of bacteria, after which the absorption efficiency declined again to approximately $48 \%$. Clearly, as shown in Table 5 and Fig 1, the absorption efficiency of kelp detritus is approximately 47 to $50 \%$, despite considerable variations in microbial biomass. This suggests that kelp debris itself represents an important source of carbon for the dominant kelp bed consumer $A$. ater, although it should be noted that the experimental kelp debris may not be identical to that which occurs in the field. It should be stressed, however, that since the $C: N$ ration of kelp debris is as high as 17:1 (Dieckmann, 1978; Newell at al., 1980) 
whilst the isolated kelp bacteria were found to be richer in nitrogen with a $\mathrm{C}: \mathrm{N}$ ratio of only $4: 1$ (V. Stuart, unpubl.), the microbial community attached to kelp debris may contribute to the nitrogen requirements of the consumer organisms utilising carbon-rich plant debris.

\section{Effect of Particle Concentration}

One of the common features which have been reported from energetic studies on bivalves using cultures of phytoplankton is that absorption efficiency, and hence scope for growth, declines at high suspended food concentrations (Thompson and Bayne, 1974; Griffiths and King, 1979). This effect occurs even at cell concentrations equivalent to the dry mass of particulate matter occurring under natural conditions in the kelp bed environment. It is clearly of interest to determine whether a decline in absorption efficiency occurs when Aulacomya ater is presented with a food supply of suspended kelp debris.

Powered ${ }^{14} \mathrm{C}$-labelled kelp detritus was aged for $6 \mathrm{~d}$ in natural seawater and fed with ${ }^{51} \mathrm{Cr}$ microspheres to Aulacomya ater at 8 different ration levels between $0.5 \mathrm{mg}^{-1}$ and $10 \mathrm{mg} \mathrm{l}^{-1}$ dry mass. The results are summarised in Table 6 which shows that in common

Table 6. Aulacomya ater. Absorption efficiency of individuals fed on kelp debris aged for $6 \mathrm{~d}$. Test individuals were held at $12.5^{\circ} \mathrm{C}$ and fed different ration levels of particles $<37 \mu \mathrm{m}$ in diameter

\begin{tabular}{|c|c|c|c|}
\hline $\begin{array}{c}\text { Detritus } \\
\text { concentration } \\
\text { (mg })^{-1} \text { dry) }\end{array}$ & $\begin{array}{c}\text { Absorption } \\
\text { efficiency } \\
( \pm \text { S.E.) }\end{array}$ & $\begin{array}{l}\text { No. of } \\
\text { runs }\end{array}$ & $\begin{array}{c}\text { No. of } \\
\text { samples }\end{array}$ \\
\hline 0.5 & $57.36( \pm 17.38)$ & 2 & 7 \\
\hline 1.0 & $64.51( \pm 9.83)$ & 2 & 7 \\
\hline 1.5 & $57.29( \pm 7.36)$ & 4 & 10 \\
\hline 3.0 & $51.31( \pm 4.78)$ & 5 & 15 \\
\hline 4.5 & $43.17( \pm 4.78)$ & 4 & 11 \\
\hline 6.0 & $41.11( \pm 7.52)$ & 2 & 11 \\
\hline 7.5 & $47.38( \pm 5.29)$ & 4 & 24 \\
\hline 10.0 & $39.39( \pm 9.69)$ & 3 & 13 \\
\hline
\end{tabular}

with those reported for other bivalves, there is an increase in absorption efficiency of the detrital diet with decrease in available food.

The decline in absorption efficiency with increase in suspended particle concentration is, however, much less than that reported by Griffiths and King (1979) for Aulacomya ater (Fig. 2) or for other mussels fed with algal suspensions (Bayne, 1976; Bayne and Newell, in press). In contrast to the results obtained on suspensions of phytoplankton, the data obtained with kelp

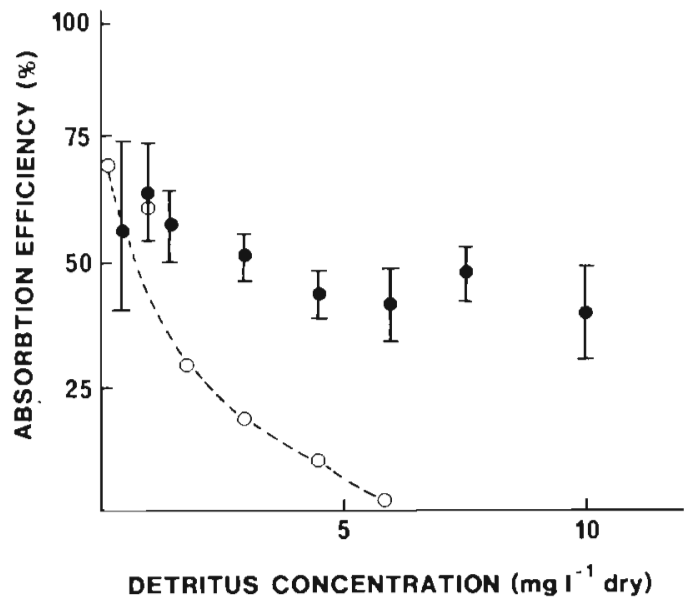

Fig. 2. Aulacomya ater. Absorption efficiency ( \pm 1 S.E.) with different concentrations of kelp aged for $6 \mathrm{~d}$ (closed circles). Open circles: data for absorption of Dunaliella primolecta (from Griffiths and King, 1979)

debris suggests that the mussels are able to maintain a positive scope for growth over the higher range of concentrations of suspended particulate matter which occur under natural conditions near to the kelp bed.

\section{CONCLUSION}

The data presented show that values for the absorption efficiency of Dunaliella primolecta cells by Aulacomya ater obtained with ${ }^{14} \mathrm{C}$-labelled food and ${ }^{51} \mathrm{Cr}$-microspheres are similar to those obtained by the Conover ratio method (Griffiths and King, 1979). This suggests that the assumption of unselective ingestion of microspheres along with the food source, which is required by the method, is valid. Provided that labelled food is presented for a limited time and the faeces are collected for a maximum time which equals that of the feeding period plus gut passage time, the ${ }^{51} \mathrm{Cr}_{\mathrm{I}}$ microsphere method allows a meaningful estimate of the utilisation of both bacteria and kelp debris components of a detrital diet.

The results suggest that, although bacterial cultures based on isolates of kelp bacteria can be absorbed with an efficiency of 67 to $70 \%$, the debris itself may also be absorbed by Aulacomya ater with an efficiency of approximately $50 \%$, despite considerable variations in the microbial component of the detritus. Many other invertebrates including copepods (Paffenhöfer and Harris, 1976; Poulet, 1976; Roman, 1977) and other crustaceans (Monk, 1977; Boyle and Mitchell, 1978) and sea urchins (Fong and Mann, 1980) are capable a exploiting detritus either directly (Seiderer et al., 1982) or indirectly by possible mediatian of micro-organisms 
(see Wainwright and Mann, 1982 and references cited therein).

The kelp debris, which forms an important component of the particulate matter potentially available for consumption by the filter-feeding community near to kelp beds, may thus represent an important source of carbon for the dominant consumer $A$. ater. In contrast to the result obtained at the highest concentrations of other food sources, the data obtained with kelp debris suggest that the mussels are able to maintain a positive scope for growth at the concentrations of suspended organic matter which occur under natural conditions in the kelp bed environment.

Acknowledgements. We are grateful to Dr. T. S. Burden of the Medical Biochemistry Dept. Univ. of Cape Town, for advice given on radio-isotope handling and construction of quench curves, and to the Dept. of Biochemistry, Univ. of Cape Town, for the extensive use of their liquid scintillation counter. We thank Miss Claire Davis of the Microbiology Dept. for advice on culturing labelled bacteria; Mr. E. S. F. Lee of the Biochemistry Dept., for writing the computer program; and Dr. D. Klumpp, for commenting on the manuscript. The receipt of a CSIR post-graduate bursary by Miss V. Stuart is gratefully acknowledged. R. C. Newell is supported by a Royal Society Senior Research Fellowship. The research was sponsored by the South African National Committee for Oceanographic Research and the Atomic Energy Board.

\section{LITERATURE CITED}

Baker, J. M., Bradnam, L. A. (1976). The role of bacteria in the nutrition of aquatic detritivores. Oecologia 24: 95-104

Bayne, B. L. (1976). Marine mussels, their ecology and physiology, Cambridge University Press, London

Bayne, B. L., Moore, M. N., Widdows, J., Livingstone, D. R., Salkeld, P. (1979). Measurements of the responses of individuals to environmental stress and pollution: studies with bivalve molluscs. Phil. Trans. R. Soc. (B) 286: 563-581

Bayne, B. L., Newell, R. C. (in press). Physiological energetics of marine molluscs. In: Wilbur, K. M., Saleuddin, A. S. M. (eds.) The biology of molluscs

Bockman, E. L., Ferguson, J. L. (1978). Blood flow in cat soleus muscle before and after isolation of its circulation. Fed. Proc. 37 (3): 875

Boyle, P. T., Mitchell, R. (1978). Absence of microorganisms in crustacean digestive tracts. Science, N. Y. 200: 1157-11.59

Calow, P., Fletcher, C. R. (1972). A new radiotracer technique involving ${ }^{14} \mathrm{C}$ and ${ }^{51} \mathrm{Cr}$ for estimating the assimilation efficiencies of aquatic primary consumers. Oecologia 9: $155-170$

Cammen, L. M. (1977). On the use of liquid scintillation counting of ${ }^{51} \mathrm{Cr}$ and ${ }^{14} \mathrm{C}$ in the twin tracer method of measuring assimilation efficiency. Oecologia 30 (3): 249-252

Cammen, L. M. (1980a). Ingestion rate: an empirical model for aquatic deposit feeders and detritivores. Oecologia 44 303-310

Cammen, L. M. (1980b). The significance of microbial carbon in the nutrition of the deposit feeding polychaete Nereis succinea. Mar. Biol. 61: 9-20
Cammen, L. M. Rublee, P., Hobbie, J. E. (1978). The significance of microbial carbon in the nutrition of the polychaete Nereis succinea and other aquatic deposit feeders. University of North Carolina, Sea Grant Pub. UNC-SG-78-12, Raleigh N. C. North Carolina State University

Conover, R. J. (1966). Assimilation of organic matter by zooplankton. Limnol. Oceanogr 11: 338-345

Cruz, A. A de la, Poe, W. E. (1975). Amino acids in salt marsh detritus. Limnol. Oceanogr 20 (1): 124-127

Darnell, R. M. (1967a). The organic detritus problem. In: Lauff, G. M. (ed.) Estuaries. Am. Ass. Advmt Sci. (83) Washington D. C.: pp. 374-375

Darnell, R. M. (1967b). Organic detritus in relation to the estuarine ecosystem. In: Lauff, G. M. (ed.) Estuaries. Am. Ass. Advmt Sci. (83) Washington D. C., pp. 375-382

Dieckmann, G. S. (1978) Aspects of growth and production of Laminaria pallida (Grev.) J. Ag. off the Cape Peninsula. $M$. Sc. thesis, University Cape Town.

Fenchel, T (1972). Aspects of the decomposer food chains in marine benthos. Verh. dt. zool. Ges. 65: 14-22

Field, J. G., Griffiths, C. L., Griffiths, R. J., Jarman, N. Zoutendyk, P., Velimirov, B., Bowes, A. (1980). Variation in structure and biomass of kelp bed communities along the south west Cape coast. Trans. R. Soc. S. Afr. 44: 145-203

Fong, W., Mann, K. H. (1980). Role of gut flora in the transfer of amino acids through a marine food chain. Can. T. Fish Aquat. Sci. 37: 88-96

Foster-Smith, B. A. (1975a). The effects of concentration of suspension on the filtration rates and pseudofaecal production for Mytilus edulis L., Cerastoderma edule (L.) and Venerupis pullastra (Montagu). J. exp. mar. Biol. 17: 1-22

Foster-Smith, B. A. (1975b). The effect of concentration of suspension and inert material on the assimilation of algae by three bivalves. J. mar biol. Ass. U. K. 55: 411-418

Fuji, A. (1962). Studies on the biology of the sea-urchin V. Food consumption of Strongylocentrotus intermedius. Jap J. Ecol. 12: 181-186

Griffiths, C. L., King, J. A. (1979). Some relationships between size, food availability and energy balance in the ribbed mussel, Aulacomya ater (Molina). Mar Biol. 51: 141-149

Griffiths, R. J. (1980). Natural food availability and assimilation in the bivalve Choromytilus meridionalis. Mar. Ecol Prog. Ser. 3: 151-156

Hargrave, B. T (1970a). The utilization of benthic microflora by Hyalella azteca (Amphipoda). J. Anim. Ecol. 39: $427-437$

Hargrave, B. T. (1970b). The effect of a deposit-feeding amphipod on the metabolism of benthic microflora. Limnol. Oceanogr. 15: 21-30

Hargrave, B. T (1971). An energy budget for a deposit feeding amphipod. Limnol. Oceanogr 16: 99-103

Hobson, R. W., Kerr, J. C., Lipp, J. A., O'Donnell, J. A., Swan, K. G. (1978). Composition of impedance theography electromagnetic flowmetry and distribution of radioactively tagged microspheres in measurement of canine hind limb blood flow. Clin. Res. 26 (1): 4 a

Jensen, K. T., Siegismund, M. R. (1980). The importance of diatoms and bacteria in the diet of Hydrobia species. Ophelia 19 (SuppI): 193-199

Kiorboe, T., Mohlenberg, F. (1981). Particle selection in suspension feeding bivalves. Mar. Ecol. Prog. Ser. 5: 291-296

Kiørboe, T., Mohlenberg, F., Nøhr, O. (1980) Feeding, particle selection and carbon absorbtion in Mytilus edulis in different mixtures of algae and resuspended bottom material. Ophelia 19: 193-205 
Kofoed, L. H. (1975). The feeding biology of Hydrobia ventrosa (Montagu). 1. The assimilation of different components of the food. J. exp. mar. Biol. Ecol. 19: 233-241

Kristensen, J. H. (1972). Carbohydrases of some marine invertebrates with notes on their food and on natural occurrence of the carbohydrates studied. Mar Biol. 14 $130-142$

Larsson, U., Hagström, A. (1979). Phytoplankton exudate release as an energy source for the growth of pelagic bacteria Mar. Biol. 52: 199-206

Lasenby, D. C., Langford, R. R. (1973). Feeding and assimilation of Mysis relicta. Limnol. Oceanogr. 18: 280-285

Linley, E. A. S., Newell, R. C. (1981). Microheterotrophic communities associated with the degradation of kelp detritus. Proc. 15th Europ. Sym. Mar. Biol., Kieler Meeresforsch. 5: 345-355

Linley, E. A. S., Newell, R. C., Bosma, S. A. (1981). Heterotrophic utilization of mucilage released during fragmentation of kelp (Ecklonia maxima and Laminaria pallida). 1. Development of microbial communities associated with the degradation of kelp mucilage. Mar. Ecol. Prog. Ser. 4: $31-41$

Lobban, C. S. (1974). A simple, rapid method of solubilizing algal tissue for scintillation counting. Limnol. Oceanogr. 19: 356-359

Marshall, S. M., Orr, A. P. (1955). On the biology of Calanus finmarchiicus VIII. Food uptake, assimilation and excretion in adult and Stage V Calanus. J. mar. biol. Ass. U. K. 34: $495-529$

Monk, D. C. (1977). The digestion of cellulose and other dictary components and the $\mathrm{pH}$ of the gut in the amphipod Gammarus pulex (L.) Freshwat. Biol. 7: 28-37

Moriarty, D. J. W. (1977). Quantification of carbon, nitrogen and bacterial biomass in the food of some penaeid prawns. Aust. J. mar. freshwat. Res. 28 (2): 113-118

Newell, R. C. (1965). The role of detritus in the nutrition of two marine deposit-feeders, the prosobranch Hydrobia ulvae and the bivalve Macoma balthica. Proc. zool. Soc. Lond. 144: $25-45$

Newell, R. C. (1979). Biology of intertidal animals, Marine Ecological Surveys Ltd, Faversham, Kent

Newell, R. C., Field, J. G., Griffiths, C. L. (1982). Energy balance and the significance of micro-organisms in a kelp bed community. Mar. Ecol. Prog. Ser. 5: 356-369

Newell, R. C., Lucas, M. I. (1981). The quantitative significance of dissolved and particulate organic matter released during fragmentation of kelp in coastal waters. Proc. 15th Europ. Symp. Mar Biol., Kieler Meeresforsch. 6: 356-369

Newell, R. C., Lucas, M. I., Velimirov, B., Seiderer, L. J (1980). The quantitative significance of dissolved organic losses following fragmentation of kelp (Ecklonia maxima and Laminaria pallida). Mar. Ecol. Prog. Ser 2: 45-59

Odum, E. P., Cruz, A. A. de la (1967). Particulate organic detritus in a Georgia salt marsh - estuarine ecosystem. In Lauff, G. M. (ed.) Estuaries. Am. Ass. Advmt Sci. (83) Washington D. C., pp. 383-388

Paffenhöffer, G. A.; Harris, R. P. (1976). Feeding, growth and reproduction of the marine planktonic copepod Pseudocalanus elongatus Boeck. J. mar. biol. Ass. U. K. 56: $327-344$
Phillipson, J. (1960). A contribution to the feeding biology of Mitopus moria (F.) (Phalangida) J. Anim. Ecol. 29: 35-43

Poulet, S. A. (1976). Feeding of Pseudocalanus minutus on living and non-living particles. Mar. Biol. 34: 117-125

Roman, M. R. (1977). Feeding of the copepod Acartia tonsa on the diatom Nitzschia closterium and brown algae (Fucus vesiculosus) detritus. Mar Biol. 42 (2): 149-157

Schleyer, M. H. (1980). A preliminary evaluation of heterotrophic utilization of a labelled algal extract in a subtidal reef environment. Mar. Ecol. Prog. Ser 3: 223-229

Seiderer, L. J., Newell, R. C., Cook, P. A. (1982). Quantitative significance of style enzymes from two marine mussels (Choromytilus meridionalis Krauss and Perna perna Linnaeus) in relation to diet. Mar. Biol. Letters (in press)

Sheppard, G., Marlow, C. G. (1971). The simultaneous measurement of ${ }^{51} \mathrm{Cr}$ and ${ }^{14} \mathrm{C}$ by liquid scintillation counting. Int. J. appl. Radiat. Isotopes 22: 125-127

Sorokin, J. I. (1968). The use of ${ }^{14} \mathrm{C}$ in the study of nutrition of acquatic animals. Mitt. int. Verein. theor. angew. Limnol. 16: $1-41$

Sorokin, J. I. (1972). Bacteria as food for coral reef fauna. Oceanology 12: 169-176

Sorokin, J. I., Panov, P. A. (1966). The use of ${ }^{14} \mathrm{C}$ for the quantitative study of the nutrition of fish larvae. Int. Rev. ges. Hydrobiol. 51: 743-753

Southwood, T R. E. (1966). Ecological methods with particular reference to the study of insect populations, Methuen, London

Tenore, K. R. (1975). Detrital utilization by the polychaete Capitella capitata. J. mar Res. 33 (3): 261-274

Thompson, R. J., Bayne, B. L. (1974). Some relationships between growth, metabolism and food in the mussel, Mytilus edulis. Mar. Biol. 27: 317-326

Tunnicliffe, V., Risk, M. J. (1977). Relationships between the bivalve Macoma balthica and bacteria in intertidal sediments: Minas Bay, Bay of Fundy. J. mar. Res. 35 (3): $499-507$

Vahl, O. (1980). Seasonal variations in seston and in the growth rate of the Iceland scallop. Chlamys islandica (O. F. Muller) from Balsfjod $70^{\circ} \mathrm{N}$. J. exp. mar biol. Ecol. 48: 195-204

Wainwright, P. F., Mann, K. H. (1982). Effect of antimicrobial substances on the ability of the mysid shrimp Mysis stenolepis to digest cellulose. Mar. Ecol. Prog. Ser. 7: 309-313

Wetzel, R. L. (1977). Carbon resources of a benthic salt marsh invertebrate Nassarius obsoletus say (Mollusca: Nassariidae). In: Wiley, M. (ed.) Estuarine processes, Vol 2. Academic Press, London

Widdows, J., Fieth, P., Worrall, C. M. (1979). Relationship between seston, available food and feeding activity in the common mussel Mytilus edulis. Mar Biol. 50: 195-207

Wightman, J. A. (1975). An improved technique for measuring assimilation efficiency by the ${ }^{51} \mathrm{Cr}-{ }^{14} \mathrm{C}$ twin tracer method. Oecologia 19: 273-284

Winter, J. E. (1978). A. review on the knowledge of suspension-feeding lamellibranchiate bivalves, with special reference to artificial aquaculture systems. Aquaculture 13: $1-33$ 